CENTRE FOR EMEA BANKING, FINANCE \& ECONOMICS

Technical Efficiency in Saudi Arabian Banks

Albert Assaf, Carlos P. Barros and Roman Matousek

$$
\text { No } 03 / 10
$$

Working Paper Series 


\title{
Technical Efficiency in Saudi Arabian Banks
}

\author{
Albert Assaf ${ }^{1}$ Carlos Pestana Barros ${ }^{2}$ and Roman Matousek $^{3}$ \\ ${ }^{1}$ Instituto de Economia e Gestão, Technical University of Lisbon, Rua Miguel Lupi, 20, 1249-078 \\ Lisbon, , Portugal.cbarros@iseg.utl.pt \\ ${ }^{2}$ Centre for Tourism and Services Research, Victoria University, Australia. albert.assaf @ vu.edu.au. \\ ${ }^{3}$ Corresponding author: Centre for EMEA Banking, Finance and Economics, London Metropolitan \\ Business School, London Metropolitan University, 84 Moorgate, London, EC2M 6SQ. E-mail: \\ r.matousek@londonmet.ac.uk.
}

\begin{abstract}
This study analyses the technical efficiency of Arabian banks using a DEA-Data Envelopment Analysis frontier model. In the first stage, a bootstrapped variable returns to scale (VRS) DEA model is used to identify the efficient scores. In the second stage, a bootstrapped truncated regression is adopted to identify the covariates that explain technical efficiency. Policy implications are derived.
\end{abstract}

Keywords: Arabian banks, DEA-data Envelopment Analysis, Double Bootstrap, Truncated Regression 


\section{Introduction}

The Saudi banking sector has undergone substantial changes over the last decade. Banks have expanded their operations and have taken advantage of scale and scope economies as well as product diversification. The driving force behind these changes has been the recent gradual liberalization of financial sector, globalization of financial markets, changes in technology, product innovation and the growth of business activities by Islamic countries in the West (El-Gamal, 2006).

The Saudi banking system is quite unique compared to the traditional banking system. It is under strict regulation imposed by SAMA (Saudi Monetary Agency) and has several distinguished factors. Firstly, Saudi banks are unique in the fact that they provide a combination of conventional banking and Islamic banking. Secondly, the overwhelming dependence on oil causes difficulties for domestic banks to diversify credit risk which consequently requires from banks to hold high levels of capital. Thirdly, the banks are funded by low cost demand deposits. ${ }^{1}$

Empirical research on banks efficiency in Arabic peninsula is still very limited as opposed to extensive research in Europe and USA. There are only several studies that tackle this issue in Islamic countries, see for example Avkiran (2009), Mostafa (2009), Emrouznejad and Anouze (2009), Hisham et al (2008), Essayyad and Madani (2003). The main motivation of the present research is to analyse the technical efficiency of Saudi Arabian banks, a richer leading oil country that aims to develop supported in the foreign earnings obtained in oil. The banks are the institutions that channel the oil funds to the companies and families and therefore are strong determinants in the allocation of capital, financial stability and the competitiveness and development of manufacturing and services (Beck et al., 2003). This paper also aims to analyse the differences in technical efficiency among purely domestic banks and foreign banks that operate on the basis of join-venture with financial institution in Saudi Arabia. Based on the results we aim to provide and discuss implications for Saudi banking.

The present paper contributes to the literature on banking performance analysing the technical efficiency of Saudi Arabia with a simultaneous two-stage DEA bootstrap model. In the first stage, Data Envelopment Analysis (DEA) is used to estimate the relative efficiency scores ranking banks according to their efficiency. In the second stage, the Simar and Wilson (2007) procedure is applied to bootstrap the DEA scores with a truncated regression. This approach allows us to obtain more reliable evidence compared to previous studies analysing the efficiency. The Simar and Wilson (2007)

\footnotetext{
${ }^{1}$ IMF claims that about $40 \%$ of total assets is funded by demand deposits.
} 
procedure ensures the efficient estimation of the second-stage estimators, which is not a property of alternative methods.

The remainder of the paper is organised as follows: in Section 2, we describe developments in the Arabian banking sector. In Section 3, we present the literature survey whilst the data is presented in Section 4. Section 5 discusses methodology. Empirical results are presented in Section 6. Finally, Section 7 concludes.

\section{Contextual Setting}

The Saudi banking system is small compared with most OECD banking systems. The monetization of the banking system measured in terms of private credits to GDP was just 37per cent in 2008. The banking system has displayed a high degree of stability and strong resilience to external shocks till 2007. The stability of the sector has been enhanced by its strict regulatory rules imposed by the Saudi Arabia Monetary Fund (SAMA).

The distinguished characteristics of the Saudi banking sector as opposed to traditional west banking systems is the blend of Islamic banking and "Islamic Windows" of conventional banking. Islamic banking also known as Islamic Shariah based banking system is different from conventional banking. The concept of Islamic banking is based on its profit-and-loss sharing paradigm (PLS). This concept is underpinned by five code of belief in Islamic finance, i.e., avoidance of Riba (interest), Gharar (uncertainty), Mysur (gambling), Haram (prohibited) and sale of the items not owned or possessed. The main features of Islamic banking have been outlined, for example, by Chong and Liu (2009), Taylor (2004).

The Islamic Banking contributes to a significant profitability of Saudi Banking sector. Islamic financial products dominate the Saudi market. Islamic banks control some $62 \%$ of total assets. It is estimated that about $40 \%$ of deposit are non interest bearing because of riba.

The gradual deregulation process of financial services allowed foreign financial institutions to provide financial services in Saudi Arabia. As a reaction to this process, domestic Saudi banks have also introduced a large scale of new products and services. The proportion of Islamic banking has increased recently significantly. Table 1 shows the share of Sharia-Compliant assets of banking sector. 
$<$ Insert Table 1 around here>

During the period 1996-2005, Saudi bank assets grew by 213 per cent, deposits by 224 per cent and capital and reserves by 248 per cent. Table 2 indicates the performance of the Saudi Banking sector from 2000 to 2007, measured in terms of ROA and ROE. The profits of the banking system showed strong growth - return on equity averaged well over 20 per cent and return on assets more than 2 per cent.

$<$ Insert Table 2 around here $>$

Saudi banks have a dominant position in retail banking with about 1,300 branches. It is expected that foreign banks increase competition for business in project finance, initial public offerings and Islamic financial instruments. But the retail side is also facing competition. There are currently thirteen commercial banks in Saudi Arabia. Table 3 lists the largest commercial banks and describes their main activities. Three banks are fully Saudi owned, seven have minority foreign ownership and one foreign bank has a branch presence - Gulf Investment Bank (Bahrain). Five banks also have a joint venture agreements with major international banks under which the latter provide management and technical support. Banks operate on the universal banking model and provide a broad range of products and services including retail and corporate banking, investment management and advice, and both domestic and international securities brokerage services.

It is important to stress that most domestic banks have some government participation. In 2005, Saudi Arabia formally joined WTO (World Trade Organization) and consequently foreign investors have been allowed to own up to $60 \%$ (previously 40\%) of any bank. But this change has not yet been fully reflected in the changes of the ownership structure. SAMA has granted ten new licenses to foreign banks since 2004, but only five banks so far opened for business. These new foreign banks are restricted to a single branch. The Gulf International Bank (Bahrain) arrived first in 2000, followed by the Emirates Bank International (United Arab Emirates), the National Bank of Kuwait, and the National Bank of Bahrain in 2002. ${ }^{2}$

$<$ Insert Table 3 around here>

\footnotetext{
${ }^{2}$ The list includes Deutsche Bank, BNP Paribas, J.P. Morgan, National Bank of Kuwait, Emirates Bank, , State Bank of India and National Bank of Pakistan.
} 


\section{Literature Survey}

Empirical research analysing banks efficiency has been widely addressed in the literature. There has been extensive use of non-parametric and parametric methods such as DEA (Data Envelopment Analysis) and stochastic frontier to measure technical efficiency (Alam, 2001; William, Peypoch and Barros, 2009 Pasiouras et al., 2008; Hahn, 2007; Ataullah and Le, 2008).

The present study analyses the technical efficiency of Saudi Arabian banks with a two-stage DEA model, where in the first stage the technical efficiency is bootstrapped (Charnes et al., 1978) and in the second stage the Simar and Wilson (2007) procedure is used to bootstrap the DEA scores with a truncated regression. The research on banks efficiency in Islamic countries is still rather limited. Hisham et al. (2008) analysed production efficiency of Islamic Banks and Conventional Bank Islamic Windows in Malaysia by using the variable returns to scale DEA model. The study showed that Islamic banks are more efficient at controlling costs than profits. The driving force of cost efficiency was resource management and economies of scale. In a follow up study, Avkiran (2009) applied network data envelopment analysis (NDEA) for banks operating in the United Arab Emirates. It was argued that NDEA is superior to the standard DEA technique since it provides adequate detail information for management to identify the specific determinants of inefficiency. Avrikan (2009) discussed that this method can be used in countries where an industry exhibits high levels of inefficiency and managerial strategies of how to eliminate the remaining inefficiencies have to be implemented.

A further strand of applied research on banking in Arabic peninsula is focused on competition by using the traditional structural and non-structural models (Turk-Arris , 2008; AlMuharani et al., 2006). Essayyad and Madani (2003) investigated concentration, efficiency, and profitability of commercial banks operating in Saudi Arabia. They found that the banking system was highly concentrated and lacked sound competitive environment. However their results focused on the 
1989- 2001 period which was characterized by major structural changes resulting from the membership of Saudi Arabia in WTO.

To our best knowledge there are no studies that apply an advanced methodological approach two stage DEA bootstrap model - for Saudi banking.

\section{Data}

Our analysis includes nine banks that currently operate in the Saudi Arabia. Data are collected from annual reports over the period 1999 - 2007 (81 observations).

The DEA two stage procedures are adopted. In the first stage a Bootstrapped DEA model is used to estimate the technical efficiency. To model the bank production process, we follow the intermediation approach (see Sealey and Lindley, 1977) and assume that banks purchase liabilities that are transformed into earning assets. Banks are assumed to produce four outputs that cover both on and off-balance sheet activities: (i) total customer loans, (ii) Securities and (iii) interbank loans. Three inputs are used to produce bank output: (iv) total employees; (v) fixed assets and (vi) total deposits. The descriptive statistics are shown in Table 4.

$<$ Insert Table 4 around here $>$

\section{Methodology}

\subsection{Efficiency Measurement}

DEA is used in the first stage for estimating the technical efficiency of Arabic banks. The motivation and early versions of the DEA models have appeared in several previous studies in the literature, so they will not be reiterated here. For a detailed review refer to Coelli et al. (1998). The model used in this study follows an output oriented assumption and can be derived for the $i$-th bank by solving the following linear programming: 


$$
\hat{\delta}_{i}=\max _{\hat{\delta}_{i}, \lambda}\left\{\delta>0 \mid \hat{\delta}_{i} y_{i} \leq \sum_{i=1}^{n} Y \lambda ; x_{i} \geq \sum_{i=1}^{n} X \lambda ; \sum_{i=1}^{n} \lambda=1 ; \lambda \geq 0\right\}, i=1 \ldots . n \text { banks }
$$

where $Y$ is vector of bank outputs, $X$ is s vector of bank inputs, $\lambda$ is a $I \times 1$ vector of constants. The value of $\hat{\delta}_{i}$ obtained is the technical efficiency score for the $i$-th firm. A measure of $\hat{\delta}_{i}=1$ indicates that the bank 1 is technically efficient, and inefficient if $\hat{\delta}_{i}>1$. This linear programming problem must be solved $n$ times, once for each bank in the sample. Note that the DEA model can also be estimated using either the constant return to scale $(\mathrm{CRS})^{3}$ or variable return to scale (VRS) assumptions and the shape of the frontier will differ depending on the scale assumptions that underline the model. In this paper we rely on the VRS assumption, as the CRS is only correct as long as it is appropriate to assume that banks are operating at an optimal level of scale. Technological advances and regulatory changes might vary across banks in various size groups, so allowing for VRS would permit modelling of the entire range of technology.

\subsection{The Bootstrap Approach}

A new debate has recently been raised in the literature regarding the statistical limitations of DEA scores. Simar and Wilson (1998, 1999, and 2007) emphasise that efficiency scores generated by DEA are strongly dependent on each other in the statistical sense, and thus using them in a second stage regression might violate the basic model assumption required by regression. A main reason for this problem is the well-known fact that the DEA efficiency score is a relative efficiency index, not an absolute efficiency index. One cannot also obtain statistical properties of DEA, as the efficiency scores are calculated rather than estimated.

Recently, Simar and Wilson (2007) proposed a procedure, based on a double bootstrap, which enables consistent inference in the second stage regression, while simultaneously constructing confidence internal and producing standard errors for the DEA efficiency scores. The bootstrap is a computer-based method which is based on the idea of resampling from an original data in order to assign statistical properties for the quantities of interest. Efron (1979) was the first to introduce method, and since then it has become a popular and powerful statistical tool. For more technical details on the method refer to Efron (1979) and Efron and Tibshirani (1993).

\footnotetext{
${ }^{3}$ A production function is said to exhibit constant return to scale (CRS) if a proportionate increase in inputs results in the same proportionate increase in outputs. The variable return to scale (VRS), on the other hand, doe not assume full proportionality between the inputs and outputs.
} 
In the case of DEA, Simar and Wilson (1998) were the first to introduce the method to obtain statistical properties of the efficiency scores, and in a follow-up paper they extended their approach to account for the impact of environmental variables ${ }^{4}$ on efficiency (Simar and Wilson, 2007). Before illustrating their procedure we first present the following model:

$$
\hat{\delta}_{i}=z_{i} \beta+\varepsilon_{i}
$$

where $z_{i}$ is a vector of management related variables which is expected to affect the efficiency of firms under consideration and $\beta$ refers to a vector of parameters with some statistical noise $\varepsilon_{i}$. A popular procedure in the literature is to use the Ordinarily Least Square (OLS) regression to estimate this relationship. However, as described in Simar and Wilson (2007), this might lead to estimation problems mainly related to the correlation and dependency problems of the efficiency scores which violate the regression assumption that $\varepsilon_{i}$ are independent of $z_{i}$. The importance of the Simar and Wilson (2007) procedure is that it produces with bias corrected estimates of $\hat{\delta}_{i}$ valid estimates for the parameters in the regression model. We describe their bootstrap algorithm in the following steps:

i. Calculate the DEA output-orientated efficiency score $\hat{\delta}_{i}$ for each bank, using the linear programming problem in (1):

$$
\hat{\delta}_{i}=\max _{\hat{\delta}_{i}, \lambda}\left\{\delta>0 \mid \hat{\delta}_{i} y_{i} \leq \sum_{i=1}^{n} Y \lambda ; x_{i} \geq \sum_{i=1}^{n} X \lambda ; \sum_{i=1}^{n} \lambda=1 ; \lambda \geq 0\right\} \text { for } i=1, \ldots n
$$

ii. Use the maximum likelihood method to estimate the truncated regression of $\hat{\theta}_{i}$ on $z_{i}$, to provide and estimate $\hat{\beta}$ of $\beta$ and an estimate $\hat{\sigma}_{\varepsilon}$ of $\sigma_{\varepsilon}$.

iii. For each bank $i=1, \ldots n$, repeat the next four steps (1-4) B times to yield a set of bootstrap estimates $\left\{\hat{\delta}_{i, b}^{*}, \mathrm{~b}=1, \ldots \mathrm{B}\right\}$.

1. Draw $\varepsilon_{i}$ from the $N\left(0, \hat{\sigma}_{\varepsilon}^{2}\right)$ distribution with left truncation at $\left(1-\hat{\beta} z_{i}\right)$

2. Compute $\delta_{i}^{*}=\hat{\beta} z_{i}+\varepsilon_{i}$

3. Construct a pseudo data set $\left(x_{i}^{*}, y_{i}^{*}\right)$, where $x_{i}^{*}=x_{i}$ and $y_{i}^{*}=y_{i} \hat{d}_{i} / d_{i}^{*}$

\footnotetext{
${ }^{4}$ These are variables that are neither inputs nor outputs but are used to mainly explain the variation in the efficiency scores.
} 
4. Compute a new DEA estimate $d_{i}^{*}$ on the set of pseudo data $\left(x_{i}^{*}, y_{i}^{*}\right)$, i.e. $Y$ and $X$ are replace by $Y^{*}=\left\{y_{i}^{*}, i=1, \ldots n\right\}$ and $X^{*}=\left\{x_{i}^{*}, i=1, \ldots n\right\}$ in ()

iv. For each bank, compute the bias corrected estimate $\hat{\hat{d}}_{i}=\hat{d}_{i}-$ biâs $_{i}$, where biâs is the bootstrap estimator of bias obtained as: bias $_{i}=\frac{1}{B} \sum_{b=1}^{B} \hat{\delta}_{i, b}^{*}-\hat{\delta}_{i}$.

v. Use the Maximum likelihood method is again used to estimate the truncated regression of $\hat{\hat{\delta}}_{i}$ on $z_{i}$, providing estimates $(\hat{\hat{\beta}}, \hat{\hat{\sigma}})$ of $\left(\beta, \sigma_{\varepsilon}\right)$.

vi. Repeat the next three steps (1-3) $B_{2}$ times to obtain a set of bootstrap estimates $\left\{\left(\hat{\hat{\beta}}_{b}^{*}, \hat{\hat{\sigma}}_{b}^{*}, b=1, \ldots . . B_{2}\right)\right\}$

1.For $i=1,,,,,, n, \varepsilon_{i}$ is drawn from $N(0, \hat{\sigma})$ with left truncation at $\left(1-\hat{\hat{\beta}} z_{i}\right)$

2. For $i=1,,,,,, n$, compute $\delta_{i}^{* *}=\hat{\hat{\beta}} z_{i}+\varepsilon_{i}$

3. The Maximum likelihood method is again used to estimate the truncated regression of $\delta_{i}^{* *}$ on $z_{i}$, providing estimates $\left(\hat{\hat{\beta}}^{*}, \hat{\hat{\sigma}}^{*}\right)$

vii. Use the bootstrap results to construct confidence intervals.

\section{Empirical Results and Discussions}

6.1 Efficiency measurement 
The VRS technical efficiency estimates the different Arabic banks, obtained from $2000^{5}$ bootstrap iterations are reported in Table 5. In order to compare our method with the traditional DEA model, we report in Table 5 the original (non-bootstrapped) DEA estimates. Due to the upward-bias in the original estimates and due to the bootstrap correction in the confidence intervals, the original estimates lie for every observation outside but close to the lower bound for the confidence interval. However, the bias corrected estimates lie for every observation inside the confidence interval. As indicated before, the applied methodology is based on the bootstrapped DEA given its statistical advantage over the traditional DEA method.

The results clearly indicate that the average efficiency score of Saudi banks has increased since 1999 to reach an average efficiency level of $90.21 \%$ in 2007, when several banks operated at a high efficiency level such as Fransi, SAAB, Jazira, and Hollandi. The lowest performing banks include Riyad and Samba. Their average technical efficiency was $86.71 \%$ and $88.84 \%$ respectively in 2007. On average Saudi banks were nearly $9.79 \%$ away from their frontier - maximum efficiency.

An investigation of each individual year indicates that the average efficiency score has gradually decreased in the period 1999-2003- before starting to increase consistently until 2007. The period of low efficiency might be related to the economic slowdown in the late 1990s and the beginning of new millennium. Low oil prices with relatively high interest rates forced banks to scale down their business activities and this might have impacted negatively on the efficiency results. In terms of the increase in efficiency, it is possible to discuss the long term impact of the restructuring and consolidation process which started in the second half of 1990s and lasted up to 2003. Banks increased their capital base that strengthened their position. This enabled them to increase the depositraising potential and their provision for doubtful and non-performing loans. Another important dimension of the restructuring process may be seen in the improvement of information technology, and development of new financial products and services. The gradual openness for new foreign banks not only from the Gulf Cooperation Council countries but also from the West is also a possible influential factor.

$<$ Insert Table 5 around here $>$

\subsection{Determinants of Technical Efficiency}

\footnotetext{
${ }^{5}$ Simar and Wilson (1998) recommended the use of 2000 bootstrap iterations to obtain reliable bootstrap estimates.
} 
In order to account for the sources of efficiency changes we have also regressed the efficiency scores on variables that are expected to have the impact on the technical efficiency. The bootstrap procedure used in this stage was explained in Section 5. The model can be expressed as follows:

$$
\hat{\delta}_{i t}=\beta_{0}+\beta_{1} \ln T A_{i t}+\beta_{2} L i q_{i t}+\beta_{3} N P M_{i t}+\beta_{4} P R_{i t}+\beta_{5} \text { Dummy }_{i t}+\beta_{6} t+\varepsilon_{i t}
$$

where $\hat{\delta}_{i t}$ is the technical efficiency scores; $\ln T A_{i t}$ is $\log$ of total assets , $L i q_{i t}$ is the liquidity, $N P M_{i t}$ is the net profit margin, $P R_{i t}$ is the payout ratio, Dummy is the ownership dummy, which is one if one for foreign banks and zero elsewhere $t$ is a time trend to capture any missing dynamics, and $\varepsilon_{i t}$ is random error representing statistical noise. The results of the model are displayed in Table 6.

Our estimation shows that technical efficiency increases with assets, signifying that large size contributes to higher technical efficiency. Another variable, the net profit margin is significant and positive; however, the value of the coefficient is rather marginal. It is expected that more efficient bank would have their net profit margins lower compared to less efficient banks. The coefficient of the liquidity ratio is also positive and significant.

Moreover, we find that the PR-payout ratio has a negative impact on the technical efficiency. In other words, less profit is retained by banks the lower is their technical efficiency. This finding has an important implication for managers. It shows that the shareholders should sacrifice their dividends and allow banks to re-invest their profit. It seems that a low level of retained profit imposes constraints on banks activities. The Saudi banks need to invest extensively in technologies, product development, human capital and branch networking. Therefore, the policy of a high PR-payout ratio does not seem to be appropriate.

A dummy variable that distinguishes purely domestic banks and Saudi banks with foreign capital is negative. This result is apparently in contradiction with the role of foreign banks, see for example, De Haas and van Lelyveld (2006) and Lensink et al. (2008). The presence of foreign capital in joint venture institutions should enhance managerial skills and technical support. In the case of 
Saudi banks, the results show that domestic banks have superior information and managerial skills within the Saudi Arabia market. Thus, it indirectly supports the hypothesis that managerial skills cannot be easily imported to the Saudi banking system mainly due to lack of expertise in specific area of Islamic banking.

\section{Conclusion}

This study has analysed the technical efficiency of Saudi Arabian banks from 1999 to 2007 by applying a two stage DEA bootstrap model. The limitations of the popular DEA approach, extensively used to estimate the efficiency of the international banks, were corrected with the use of an advanced bootstrap approach. The overall goal was to improve the accuracy and consistency of DEA results and to provide bank policy makers with more reliable evidences on the possible reasons of efficiency variations between the different Arabic banks.

The general conclusion is that Saudi Arabian banks are currently operating in a high efficient environment. Notwithstanding, our results show that there is room for Saudi banks to increase their efficiency. The most efficient bank in the period (Ryad) should be used as benchmark for the least efficient banks. We have also found that Saudi banks with foreign capital have to improve their technical efficiency. This result is in contradiction with the general notion that foreign capital brings managerial skills.

The present study can provide a starting point for further investigation and validation into the efficiency of the Arabic bank sector. This strand of research can provide important information for policy makers as for the openness of Saudi banking to new banks. Therefore, more investigation with alternative models can cross validate the present research. 


\section{References}

Al-Muhrani, S., Matthews, K., \& Khabari,Y. (2006). Market Structure and competitive conditions in the Arab GCC banking system. Journal of Banking and Finance, 30, 3487-3501.

Alam, I. M. S. (2001). A Non-Parametric Approach for Assessing Productivity Dynamics of Large Banks. Journal of Money, Credit and Banking, 33, 121-139.

Ataullah, A.,\& Le, H. (2008). Economic reforms and bank efficiency in developing countries: the case of the Indian banking industry. Applied Financial Economics, 16, 653- 663. 
Avkiran, N.K.(2009). Opening the blac box of efficiency analysis: An Illustration with UAE banks. Omega, 37, 930-941.

Barros, C.P., Ferreira, C., \& Williams, J. (2007). Analysing the Determinants of Performance of the Best and Worst European banks: A Mixed Logit Approach. Journal of Banking and Finance, 31, 2189-2203.

Beck, T., Demirgüç-Kunt, A., \& Levine, R. (2003). Law, endowments, and finance. Journal of Financial Economics, 70, 137-181.

Coelli, T., Prasada Rao, D.S., \& Battese, G. E. (1998). An Introduction to Efficiency and Productivity Analysis. Boston: Kluwer, Academic Publishers).

De Haas, R., \& van Lelyveld, I. (2006). Foreign banks and credit stability in Central and Eastern Europe: A panel data analysis. Journal of Banking \& Finance, 30, 1927-1952.

El-Gamal, M. A. (2006). Islamic Finance, Law, Economics, and Practice. Cambridge: Cambridge University Press.

Essayyad, M., \& Madani, H. (2003). Investigating bank structure of an open petroleum economy: the case of Saudi Arabia. Journal Managerial Finance, 29, 73 - 92.

Emrouznejad, A., Anouze, A.L. (2009), A note on the modeling the efficiency of top Arab banks, Expert Systems with Applications, 36, 5741-5744.

Hahn, F.R. (2007). Domestic mergers in the Austrian banking sector: a performance analysis. Applied Financial Economics, 17, 185-196.

Hisham, K.M., Sauman, M.S., \& Rohani, M. (2008). Assessing production efficiency of Islamic banks and conventional bank Islamic windows in Malaysia. International Journal of Business and Management Research, 1, 31-48.

Lensink, R., Meesters, A., \& Naaborg, I. (2008). Bank efficiency and foreign ownership: Do good institutions matter?. Journal of Banking and Finance, 32, 834-844.

Mostafa, M., M. (2009). Modeling the efficiency of top Arab banks: A DEA-neural network approach, Expert Systems with Applications, 36, 309-320.

Pasiouras, F., Liadaki, A., \& Zopounidis, C. (2008). Bank efficiency and share performance: Evidence from Greece. Applied Financial Economics, 18, 1121-1130. 
Sealey, C., \& Lindley, J.T. (1977). Inputs, outputs and a theory of production and cost at depository financial institution. Journal of Finance, 32, 1251-1266.

Simar, L., \& Wilson, P. W. (1998). Sensitivity Analysis of Efficiency Scores: How to Bootstrap in Nonparametric Frontier Models. Management Science, 44, 49-61.

Simar, L.,\& Wilson, P.W.( 1999). Estimating and bootstrapping Malmquist indices. European Journal of Operational Research, 115, 459-471.

Simar, L., \&Wilson, P.W. (2007). Estimation and inference in two stage, semi-parametric models of productive efficiency. Journal of Econometrics, 136, 31-64.

Taylor, J.M. (2004). Understanding and Supporting Islamic Finance: Product differentiation and international standards. Forum on Islamic Finance, Harvard University.

Turk-Ariss, R. (2009). Competitive behaviour in Middle East and North Africa banking systems. The Quarterly Review of Economics and Finance, forthcoming

Williams, J., Peypoch, N., \& Barros, C.P. (2009). The Luenberger indicator and productivity growth: A note on the European savings banks sector. Applied Economics (forthcoming).

Table 1. Sharia-Compliant assets of banking sector (percentage of total banking sector assets) 


\begin{tabular}{|l|l|l|l|l|l|}
\hline & 1999 & 2000 & 2001 & 2002 & 2003 \\
\hline On balance sheet & 11.2 & 13.0 & 15.0 & 17.0 & 21.0 \\
\hline Off balance sheet & 1.7 & 2.1 & 2.3 & 2.0 & 2.3 \\
\hline
\end{tabular}

Source: International Monetary Fund

Table 2. Performance of Saudi Arabia Banking Sector Performance (\%)

\begin{tabular}{|l|c|c|c|c|c|c|c|c|}
\hline & 2000 & 2001 & 2002 & 2003 & 2004 & 2005 & 2006 & 2007 \\
\hline ROA & 2.15 & 2.24 & 2.11 & 2.23 & 2.66 & 3.75 & 4.26 & 2.92 \\
\hline ROE & 20.12 & 20.58 & 19.68 & 21.19 & 24.10 & 30.08 & 31.30 & 22.85 \\
\hline Net Profit Margin & 50.43 & 51.44 & 50.12 & 50.07 & 58.17 & 66.77 & 69.41 & 61.79 \\
& & & & & & & & \\
\hline
\end{tabular}

Table 3. Saudi Arabia Banks 


\begin{tabular}{|c|c|}
\hline Bank name & Description of Bank's Activity \\
\hline Al Jazira Bank & $\begin{array}{l}\text { Bank that provides Shari'ah-compliant financial services, } \\
\text { including personal banking, business banking, investment } \\
\text { banking \& e-banking. }\end{array}$ \\
\hline $\begin{array}{l}\text { Al Rajhi Banking \& } \\
\text { Investment corporation }\end{array}$ & $\begin{array}{l}\text { Bank formed by the takeover of Arab Bank Limited in } \\
1980 \text {; offers commercial and Islamic banking products } \\
\text { besides services in investment, mutual funds and assets } \\
\text { management, local and international equity trading, foreign } \\
\text { exchange and treasury }\end{array}$ \\
\hline Arab National Bank (ANB) & $\begin{array}{l}\text { Bank formed by the takeover of Arab Bank Limited in } \\
1980 \text {; offers commercial and Islamic banking products } \\
\text { besides services in investment, mutual funds and assets } \\
\text { management, local and international equity trading, foreign } \\
\text { exchange and treasury. }\end{array}$ \\
\hline Banque Saudi Fransi & $\begin{array}{l}\text { Saudi Arabian joint stock company affiliated with Calyon } \\
\text { of France; it is a full service commercial bank that provides } \\
\text { comprehensive financial services and products in Saudi } \\
\text { Arabia and other markets; offers several Islamic banking } \\
\text { products }\end{array}$ \\
\hline Riyad Bank & $\begin{array}{l}\text { Retail \& corporate bank with a network of nearly } 200 \\
\text { branches and } 618 \text { automated teller machines across the } \\
\text { Kingdom. }\end{array}$ \\
\hline $\begin{array}{l}\text { SABB (formerly Saudi British } \\
\text { Bank) }\end{array}$ & $\begin{array}{l}\text { Commercial bank with a network of } 73 \text { branches across } \\
\text { Saudi Arabia ( } 13 \text { exclusive ladies' sections/branches); } \\
\text { associate company of the HSBC Group; head office is in } \\
\text { Riyadh; activities: personal banking, investment banking, } \\
\text { Islamic banking, treasury etc. }\end{array}$ \\
\hline Samba Financial Group & $\begin{array}{l}\text { Internet access service of Samba, one of the largest banks in } \\
\text { the Middle East with } 62 \text { branches, } 253 \text { ATMs, three global } \\
\text { investment centres. }\end{array}$ \\
\hline Saudi Hollandi Bank & $\begin{array}{l}\text { First bank in Saudi Arabia, originally set up to serve } \\
\text { pilgrims from the Dutch East Indies (now Indonesia); today } \\
\text { it is a Saudi joint stock company, } 40 \% \text { owned by ABN } \\
\text { Amro; offers personal banking and corporate banking } \\
\text { services and mutual funds. }\end{array}$ \\
\hline Saudi Investment Bank (SAIB) & $\begin{array}{l}\text { Commercial bank whose activities include personal } \\
\text { banking, Islamic banking, corporate banking, investment } \\
\text { banking, treasury \& electronic banking; shareholders } \\
\text { include J.P. Morgan Chase, Mizuho Corporate Bank \& } \\
\text { Saudi investors }\end{array}$ \\
\hline
\end{tabular}

Table 4. Descriptive Statistics of the Data 


\begin{tabular}{lccccc}
\hline \multicolumn{1}{c}{ Variable } & Mean & St.Dev & Median & Min & Max \\
\hline Total Employees & 6584 & 5830 & 3642 & 672 & 19493 \\
Fixed Assets & 33960654963 & 1305400000 & 512640000 & 38930000 & 80553000000 \\
Total Deposits & 39614000000 & 24048000000 & 349800000000 & 2769111000 & 115810000000 \\
Customer Loans & 23082000000 & 19182000000 & 19162000000 & 226884000 & 80553000000 \\
Securities & 2365487062 & 1555812392 & 2000000000 & 10000000 & 7096219000 \\
Interbank Loans & 5532705704 & 4379740749 & 4427328000 & 157165000 & 177980000000 \\
\hline
\end{tabular}


Table 5 Bootstrapped Efficiency Results

\begin{tabular}{|c|c|c|c|c|c|c|c|c|c|c|c|c|c|}
\hline Year & Bank & Original & Bootstrapped & Bias & Lower Bound & Upper Bound & Year & Bank & Original & Bootstrapped & Bias & Lower Bound & Upper Bound \\
\hline 1999 & Riyad & 1.0000 & 0.9364 & 0.0031 & 0.8517 & 0.9975 & 2000 & Riyad & 1.0000 & 0.9432 & 0.0025 & 0.8594 & 0.9966 \\
\hline 1999 & Jazira & 1.0000 & 0.8368 & 0.0581 & 0.6749 & 0.9973 & 2000 & Jazira & 0.8685 & 0.8283 & 0.0019 & 0.7498 & 0.8660 \\
\hline 1999 & SAIB & 1.0000 & 0.8298 & 0.0631 & 0.6599 & 0.9974 & 2000 & SAIB & 0.9971 & 0.9414 & 0.0037 & 0.8377 & 0.9944 \\
\hline 1999 & Hollandi & 0.9413 & 0.8963 & 0.0012 & 0.8335 & 0.9384 & 2000 & Hollandi & 0.8624 & 0.8246 & 0.0005 & 0.7846 & 0.8602 \\
\hline 1999 & Fransi & 1.0000 & 0.8367 & 0.0602 & 0.6609 & 0.9971 & 2000 & Fransi & 0.6931 & 0.6687 & 0.0001 & 0.6524 & 0.6909 \\
\hline 1999 & SAAB & 1.0000 & 0.8371 & 0.0577 & 0.6621 & 0.9967 & 2000 & SAAB & 0.9837 & 0.9370 & 0.0011 & 0.8756 & 0.9808 \\
\hline 1999 & ANB & 0.7156 & 0.6968 & 0.0001 & 0.6707 & 0.7140 & 2000 & RAJHI & 0.6267 & 0.6110 & 0.0001 & 0.5887 & 0.6253 \\
\hline 1999 & SAMBA & 0.9232 & 0.8954 & 0.0002 & 0.8638 & 0.9203 & 2000 & SAMBA & 0.8835 & 0.8599 & 0.0001 & 0.8335 & 0.8810 \\
\hline \multirow[t]{2}{*}{1999} & RAJHI & 1.0000 & 0.9647 & 0.0006 & 0.9176 & 0.9979 & 2000 & ANB & 0.9725 & 0.9384 & 0.0008 & 0.8732 & 0.9699 \\
\hline & Average & 0.9533 & 0.8589 & & & & & Average & 0.8764 & 0.8392 & & & \\
\hline Year & Bank & Original & Bootstrapped & Bias & Lower Bound & Upper Bound & Year & Bank & Original & Bootstrapped & Bias & Lower Bound & Upper Bound \\
\hline 2001 & Riyad & 0.9861 & 0.9465 & 0.0014 & 0.8735 & 0.9837 & 2002 & Riyad & 0.9707 & 0.9418 & 0.0004 & 0.9019 & 0.9682 \\
\hline 2001 & Jazira & 0.8401 & 0.8125 & 0.0005 & 0.7638 & 0.8384 & 2002 & Jazira & 0.7962 & 0.7775 & 0.0002 & 0.7460 & 0.7945 \\
\hline 2001 & SAIB & 1.0000 & 0.9410 & 0.0020 & 0.8708 & 0.9970 & 2002 & SAIB & 0.9134 & 0.8593 & 0.0021 & 0.7865 & 0.9111 \\
\hline 2001 & Hollandi & 0.9946 & 0.9513 & 0.0007 & 0.9070 & 0.9919 & 2002 & Hollandi & 0.7644 & 0.7398 & 0.0001 & 0.7183 & 0.7628 \\
\hline 2001 & Fransi & 0.7058 & 0.6800 & 0.0002 & 0.6480 & 0.7041 & 2002 & Fransi & 0.7306 & 0.7080 & 0.0001 & 0.6896 & 0.7283 \\
\hline 2001 & SAAB & 0.7218 & 0.6975 & 0.0001 & 0.6749 & 0.7199 & 2002 & SAAB & 0.7746 & 0.7506 & 0.0001 & 0.7296 & 0.7728 \\
\hline 2001 & ANB & 0.5707 & 0.5540 & 0.0001 & 0.5327 & 0.5695 & 2002 & RAJHI & 0.5235 & 0.5108 & 6.5147 & 0.4956 & 0.5221 \\
\hline 2001 & SAMBA & 0.8644 & 0.8460 & 0.0001 & 0.8232 & 0.8624 & 2002 & SAMBA & 0.8743 & 0.8565 & 0.0001 & 0.8346 & 0.8723 \\
\hline \multirow[t]{2}{*}{2001} & RAJHI & 0.9503 & 0.9082 & 0.0012 & 0.8372 & 0.9472 & 2002 & ANB & 1.0000 & 0.9114 & 0.0049 & 0.8354 & 0.9970 \\
\hline & Average & 0.8482 & 0.8152 & & & & & Average & 0.8164 & 0.7840 & & & \\
\hline Year & Bank & Original & Bootstrapped & Bias & Lower Bound & Upper Bound & Year & Bank & Original & Bootstrapped & Bias & Lower Bound & Upper Bound \\
\hline 2003 & Riyad & 0.9707 & 0.9386 & 0.0004 & 0.8934 & 0.9686 & 2004 & Riyad & 0.9729 & 0.9407 & 0.0003 & 0.9110 & 0.9701 \\
\hline 2003 & Jazira & 0.7899 & 0.7730 & 8.4424 & 0.7563 & 0.7878 & 2004 & Jazira & 0.8217 & 0.7941 & 0.0002 & 0.7698 & 0.8198 \\
\hline 2003 & SAIB & 1.0000 & 0.8862 & 0.0115 & 0.7868 & 0.9976 & 2004 & SAIB & 0.9479 & 0.8944 & 0.0019 & 0.8256 & 0.9457 \\
\hline 2003 & Hollandi & 0.8902 & 0.8561 & 0.0003 & 0.8236 & 0.8875 & 2004 & Hollandi & 0.8920 & 0.8619 & 0.0002 & 0.8350 & 0.8890 \\
\hline 2003 & Fransi & 0.7754 & 0.7511 & 0.0001 & 0.7330 & 0.7735 & 2004 & Fransi & 0.8485 & 0.8182 & 0.0002 & 0.7930 & 0.8460 \\
\hline 2003 & SAAB & 0.8710 & 0.8465 & 0.0001 & 0.8256 & 0.8688 & 2004 & SAAB & 0.8635 & 0.8347 & 0.0001 & 0.8129 & 0.8606 \\
\hline 2003 & ANB & 0.4723 & 0.4612 & 4.6606 & 0.4472 & 0.4707 & 2004 & RAJHI & 0.4198 & 0.4082 & 6.9305 & 0.3913 & 0.4188 \\
\hline 2003 & SAMBA & 0.8536 & 0.8341 & 0.0001 & 0.8094 & 0.8517 & 2004 & SAMBA & 0.8936 & 0.8478 & 0.0016 & 0.7750 & 0.8905 \\
\hline
\end{tabular}




\begin{tabular}{|c|c|c|c|c|c|c|c|c|c|c|c|c|c|}
\hline 2003 & RAJHI & 0.9530 & 0.9198 & 0.0004 & 0.8807 & 0.9503 & 2004 & ANB & 0.9641 & 0.9182 & 0.0011 & 0.8663 & 0.9613 \\
\hline & Average & 0.8418 & 0.8074 & & & & & Average & 0.8471 & 0.8131 & & & \\
\hline Year & Bank & Original & Bootstrapped & Bias & Lower Bound & Upper Bound & Year & Bank & Original & Bootstrapped & Bias & Lower Bound & Upper Bound \\
\hline 2005 & Riyad & 1.0000 & 0.9183 & 0.0035 & 0.8594 & 0.9972 & 2006 & Riyad & 0.9711 & 0.9269 & 0.0012 & 0.8651 & 0.9690 \\
\hline 2005 & Jazira & 0.8207 & 0.7930 & 0.0002 & 0.7685 & 0.8188 & 2006 & Jazira & 1.0000 & 0.8844 & 0.0103 & 0.8067 & 0.9975 \\
\hline 2005 & SAIB & 1.0000 & 0.9141 & 0.0060 & 0.8051 & 0.9973 & 2006 & SAIB & 1.0000 & 0.8821 & 0.0132 & 0.7895 & 0.9970 \\
\hline 2005 & Hollandi & 1.0000 & 0.9494 & 0.0011 & 0.8914 & 0.9975 & 2006 & Hollandi & 1.0000 & 0.9332 & 0.0046 & 0.8149 & 0.9971 \\
\hline 2005 & Fransi & 0.9829 & 0.9519 & 0.0004 & 0.9160 & 0.9810 & 2006 & Fransi & 1.0000 & 0.9270 & 0.0033 & 0.8498 & 0.9974 \\
\hline 2005 & SAAB & 0.9845 & 0.9576 & 0.0003 & 0.9263 & 0.9816 & 2006 & SAAB & 1.0000 & 0.9481 & 0.0016 & 0.8841 & 0.9971 \\
\hline 2005 & ANB & 0.6235 & 0.6003 & 0.0004 & 0.5613 & 0.6219 & 2006 & RAJHI & 0.9159 & 0.8823 & 0.0009 & 0.8211 & 0.9132 \\
\hline 2005 & SAMBA & 0.9212 & 0.8861 & 0.0006 & 0.8414 & 0.9197 & 2006 & SAMBA & 0.9965 & 0.9464 & 0.0016 & 0.8750 & 0.9939 \\
\hline \multirow[t]{2}{*}{2005} & RAJHI & 0.9865 & 0.9397 & 0.0009 & 0.8926 & 0.9839 & 2006 & ANB & 0.9878 & 0.9338 & 0.0024 & 0.8485 & 0.9849 \\
\hline & Average & 0.9244 & 0.8789 & & & & & Average & 0.9857 & 0.9182 & & & \\
\hline Year & Bank & Original & Bootstrapped & Bias & Lower Bound & Upper Bound & & & & & & & \\
\hline 2007 & Riyad & 1.0000 & 0.8671 & 0.0215 & 0.7438 & 0.9974 & & & & & & & \\
\hline 2007 & Jazira & 0.9421 & 0.9011 & 0.0006 & 0.8629 & 0.9381 & & & & & & & \\
\hline 2007 & SAIB & 0.9999 & 0.9418 & 0.0037 & 0.8313 & 0.9976 & & & & & & & \\
\hline 2007 & Hollandi & 1.0000 & 0.9070 & 0.0077 & 0.7864 & 0.9973 & & & & & & & \\
\hline 2007 & Fransi & 0.9758 & 0.9008 & 0.0071 & 0.8196 & 0.9972 & & & & & & & \\
\hline 2007 & SAAB & 0.9985 & 0.9240 & 0.0035 & 0.8498 & 0.9972 & & & & & & & \\
\hline 2007 & ANB & 0.8992 & 0.8958 & 0.0084 & 0.8087 & 0.9978 & & & & & & & \\
\hline 2007 & SAMBA & 0.9321 & 0.8884 & 0.0098 & 0.7997 & 0.9268 & & & & & & & \\
\hline \multirow[t]{2}{*}{2007} & RAJHI & 0.9452 & 0.8926 & 0.0088 & 0.8022 & 0.9376 & & & & & & & \\
\hline & Average & 0.9659 & 0.9021 & & & & & & & & & & \\
\hline
\end{tabular}


Table 6. Bootstrapped Truncated Regression

\begin{tabular}{|l|c|c|}
\hline \multicolumn{1}{|c|}{ Variable } & Coefficient & t-statistic \\
\hline Constant & $-0.2612^{* *}$ & 2.790 \\
\hline $\ln T A$ & $0.0479^{* *}$ & 3.139 \\
\hline$N P M$ & $0.0026^{*}$ & 2.166 \\
\hline Liq & $0.3566^{* *}$ & 3.822 \\
\hline$P R$ & $-0.0008^{* *}$ & -2.337 \\
\hline Dummy & $-0.0303^{*}$ & 2.185 \\
\hline$t$ & $0.0020^{* *}$ & 3.333 \\
\hline Variance & $0.1400^{* *}$ & 7.690 \\
\hline
\end{tabular}

** significant at the 5\% confidence level; * significant at

the $10 \%$ confidence level; total number of iterations $=2000$ 